\title{
Ruellia domatiata (Acanthaceae), a striking new species from Madagascar
}

\author{
Iain Darbyshire ${ }^{1}$ D, Erin A. Tripp ${ }^{2}$ \& Guy E. Onjalalaina ${ }^{3}$
}

Summary. The new species Ruellia domatiata I. Darbysh. \& E. Tripp from northern Madagascar is described and illustrated and its affinities within the genus are discussed. This striking new species is currently assessed as Critically Endangered using the categories and criteria of the IUCN Red List. The presence of tuft-domatia on the undersurface of the leaves, a rare occurrence in the Acanthaceae family, is noted.

Key Words. domatia, Dyschoriste, Eusiphon, IUCN conservation assessment, pollen, stigma, taxonomy.

\section{Introduction}

Whilst botanising in the Antsiranana region of northern Madagascar in 1988, Dr Martin Cheek and colleagues collected specimens of a striking, large-flowered Acanthaceae from dry forest on limestone in the Ankarana area (Cheek et al. B1409) which could not be matched to any known species in the family. The combination of left-contort corolla aestivation, presence of a filament curtain within the corolla tube and four didynamous stamens places this species unambiguously within the tribe Ruellieae (Tripp et al. 2013) but the generic placement was somewhat more problematic. It was provisionally identified at the Kew Herbarium (K) by Dr Kaj Vollesen as "Dyschoriste sp. nov. aff. D. siphonantha Kuntze vel gen. nov. aff." but remained undescribed in the absence of additional material including mature fruits. Whilst collecting in the same area in 1996, Olivier Andrianantoanina (Missouri Botanical Garden) and colleague collected a second specimen of this species, this one including mature fruits, thus allowing a complete description to be prepared.

On cursory inspection, the markedly tubular calyx with five linear lobes in this species appears to point towards Dyschoriste Nees. This is also supported by, or at least not contradicted by, the presence of a 4-seeded capsule with seeds covered by hairs, spreading axillary inflorescences and somewhat zygomorphic, 5-lobed corollas with four included, didynamous stamens. In tropical Africa, this combination of characters would point towards Dyschoriste as the most likely genus. Indeed, the species could potentially key to that genus using the Flore de Madagascar et des Comores account of tribe Ruellieae by Benoist (1967). However, on closer inspection, several characters are noted that would represent anomalies for Dyschoriste. Firstly, the anthers are muticous at the base whilst in Dyschoriste these are typically appendaged. However, this character is not universal in Dyschoriste - in Madagascar, D. gracilicaulis (Benoist) Benoist is noted to have non-apiculate anthers (Benoist 1967), and some species in the Caribbean and southeast U.S.A. also lack anther appendages (Tripp et al. 2013). Secondly, the tubular portion of the calyx is of \pm equal thickness throughout and lacks hyaline margins whilst in Dyschoriste the tubular portions between the five main veins of the lobes are \pm markedly thinner and the margins are hyaline (Vollesen 2008; Tripp et al. 2013) and often rupture at fruit dehiscence. Thirdly, the stigma comprises one minute lobe and a second elongated lobe with an involute, irregularly wavy margin whilst in Dyschoriste the elongate stigma lobe is flat and with a straight margin (Vollesen 2008). Finally, and most informatively with respect to traditional taxonomic concepts within Acanthaceae and Ruellieae (Scotland \& Vollesen 2000; Tripp et al. 2013), inspection of the pollen grains under SEM revealed a pollen type very different to that of Dyschoriste. The grains extracted from Cheek et al. B1409 are somewhat degraded but are sufficient to note that they are globose with a coarsely reticulate exine throughout and lack pseudocolpi (Fig. 1). In contrast, pollen of Dyschoriste is prolate with thickened sexine lips around the three short

\footnotetext{
Accepted for publication 19 January 2017. Published online 29 March 2017

1 Herbarium, Royal Botanic Gardens, Kew, Richmond, Surrey, TW9 3AB, UK. e-mail: i.darbyshire@kew.org

2 Museum of Natural History (COLO Herbarium), University of Colorado, Boulder, C105 Ramaley Hall, Campus Box 334, Boulder, CO, 80309-0350, USA.

3 Kew Madagascar Conservation Centre, Lot II J 131 B, Ambodivoanjo, Ivandry, Antananarivo, Madagascar.
} 


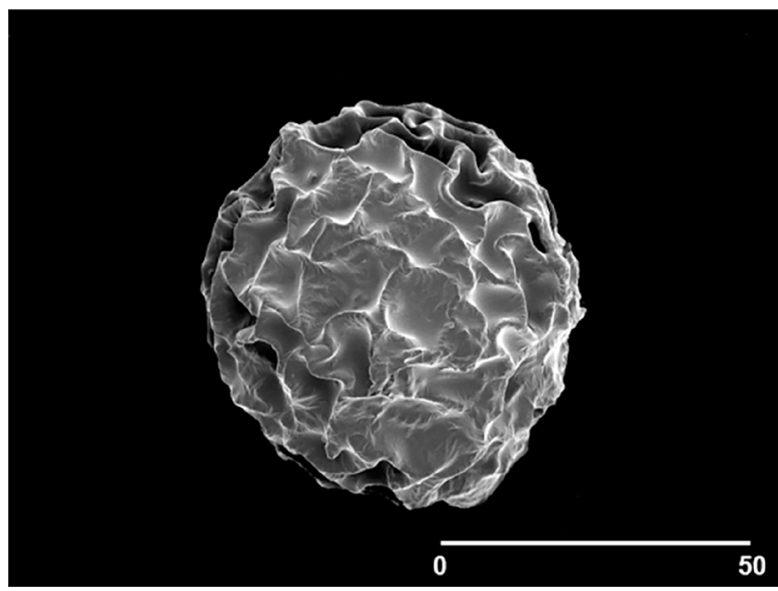

Fig. 1. SEM image of the pollen of Ruellia domatiata.

apertures and with 12 or more pseudocolpi (see Scotland \& Vollesen 2000: fig. 15B; Tripp et al. 2013: fig. 14BB).

The pollen type of the new species, as well as stigma morphology, closely resembles Ruellia L. (see Scotland \& Vollesen 2000: figs. 16, 17A - B; Tripp et al. 2013: fig. 14H N). Many Ruellia species have a deeply divided calyx without a conspicuous tubular portion and most have more than 4 seeds in the capsule, but there are exceptions to both characters. In Madagascar, R. geayi (Benoist) E. Tripp and R. quartziticola Callm., E. Tripp \& Phillipson were previously treated in the endemic Malagasy genus Eusiphon Benoist. This lineage, now understood to be nested within Ruellia (Tripp et al. 2013), is characterised by having both a tubular calyx and a 4-seeded capsule. In fact, the calyces and capsules of these two species are very similar to the new species, although they otherwise differ markedly in corolla morphology — the new species has a rather short, infundibuliform corolla tube whereas in $R$. geayii and $R$. quartziticola the corolla tube is longcylindrical. In light of the morphological evidence, the new species most likely represents a member of Ruellia and is related to $R$. geayii and allies. This hypothesis has recently been confirmed by ongoing molecular analyses on the Old World lineages of Ruellia (Tripp \& Darbyshire 2017). Therefore, the new species $R$. domatiata I. Darbysh. \& E. Tripp is formally described below.

Benoist (1967) recorded 31 species of Ruellia in Madagascar, all but one of which are endemic to the island. Recent molecular analyses (Tripp 2007; Tripp et al. 2013) have demonstrated that Eusiphon and two other Malagasy genera, Benoicanthus Heine \& A. Raynal and Pseudoruellia Benoist, are nested within Ruellia. With this expansion of the generic circumscription, together with the addition of the new species $R$. domatiata described here, 35 accepted species of Ruellia are currently known from Madagascar (Madagascar Catalogue 2015), making it the third largest genus of Acanthaceae on the island. However, as with most genera of Acanthaceae on Madagascar (Darbyshire et al. 2014; Onjalalaina \& Darbyshire 2016), Ruellia is greatly in need of critical revision there and the number of species is likely to continue to grow.

\section{Materials and Methods}

Herbarium specimens of the new species were analysed at $\mathrm{K}$ using standard herbarium practices. Prior to dissection, the flower was soaked in Aerosol OT 5\% solution; all other characters were measured on dry material. All duplicates seen by the authors are marked "!".

For the pollen analysis, one anther was removed from Cheek et al. B1409, dissected to extract the pollen and mounted onto a SEM stub coated with doublesided sticky tape. The preparation was then sputter coated with platinum and examined using a Hitachi S4700 cold field emission SEM at $2 \mathrm{kV}$.

The species conservation assessment was prepared following the Categories and Criteria of IUCN (2012). Area of Occupancy (AOO) was calculated using a grid cell size of $4 \mathrm{~km}^{2}$ following the guidance of the IUCN Standards and Petitions Subcommittee (2014).

Ruellia domatiata I. Darbysh. Eं E. Tripp. Type: Madagascar, Diego-Suarez, S of Anivorano N, environs of Ambalabao, Cheek, Rakotozafy E Abdallah Salam B1409 (holotype K 000963389!; isotypes BR!, CAS!, COLO!, K 000963390!, K 000963391!, MO!, P!, TAN).

http://www.ipni.org/urn:lsid:ipni.org:names:77159803-1

Shrub 1.5 - $3 \mathrm{~m}$ tall; young, non-woody stems quadrangular, glabrous except for stiff gland-tipped hairs in the leaf axils; mature stems becoming more terete, woody with pale brown bark with prominent lenticels. Leaves chartaceous, ovate to oblong-ovate or oblong-elliptic, largest leaves $8.4-16 \times 3.6-6 \mathrm{~cm}$, base often markedly asymmetric, obtuse to rounded or one side more acute, margin entire, apex caudate, sparsely pubescent on margin and midrib above, elsewhere glabrous except for tuft-domatia in axils of lateral veins against midrib comprising tufts of curled, buff-coloured multicellular hairs; both surfaces with numerous sessile patelliform glands and with numerous linear cystoliths visible with magnification; lateral veins $6-8(-10)$ pairs, strongly ascending, somewhat impressed above, prominent beneath; petiole 4 $13 \mathrm{~mm}$ long, pubescent adaxially. Inflorescences axillary, lax, pendulous $1-3(-4)$-flowered cymes, dichasial or often monochasial or central flower of dichasium suppressed; primary peduncle 30 - $110 \mathrm{~mm}$ long, wiry, reddish-brown, proximal portion with short yellowish retrorse hairs adaxially, these becoming 
sparse in distal portion; secondary peduncles 18 $33 \mathrm{~mm}$ long; bracteoles very early-caducous leaving a pair of prominent scars, linear-lanceolate, $\pm 9 \times 2 \mathrm{~mm}$; pedicels $1.2-2.5 \mathrm{~mm}$ long. Calyx tube $4.5-5 \mathrm{~mm}$ long in flower, up to $7.5 \mathrm{~mm}$ long in fruit; lobes 5 , linear, somewhat unequal in length with posterior lobe longest, 7.5 - $12 \mathrm{~mm}$ long, glabrous externally, appressed-pubescent internally, external surface with dense cystoliths conspicuous above base which is thickened and darker. Corolla pink-purple with white throat, 33 - $36 \mathrm{~mm}$ long during anthesis, glabrous externally except for few stiff hairs on lobe apices; tube infundibuliform, somewhat curved, $21.5-24 \mathrm{~mm}$ long, basal cylindrical portion $6.5-8.5 \times 2.2-3 \mathrm{~mm}$, throat abruptly expanded, particularly ventrally, $7.5-$ $12 \mathrm{~mm}$ wide at mouth (flattened); limb 5-lobed, zygomorphic, aestivation left-contort, lateral and adaxial lobes spreading or somewhat reflexed at anthesis; adaxial and lateral lobes oblong, 10.5 - $12 \times 7.5-8$ $\mathrm{mm}$, apices emarginate; abaxial lobe ovate when flattened, $10-12 \times 9.5 \mathrm{~mm}$, but margin strongly revolute such that lobe appears lanceolate, apex notched. Stamens included, didynamous, with free portion of filaments $\pm 10 \mathrm{~mm}$ long (longer pair) or \pm $4 \mathrm{~mm}$ long (shorter pair), glabrous, fused filament curtain ciliate; anthers $3.5-3.8 \mathrm{~mm}$ long, apex with a conical extension of connective tissue, thecae muticous at base. Pollen globose, $60-65 \mu \mathrm{m}$ in diam., triaperturate, with coarsely reticulate exine (Fig. 1). Ovary ovoid, $2.5 \mathrm{~mm}$ long, glabrous; disk cupular with a protruding lobe on one side; style filiform, 18 $22 \mathrm{~mm}$ long, glabrous; stigma bilobed, posterior lobe minute, anterior lobe linear, 1.2 - $1.5 \mathrm{~mm}$ long, flattened but with markedly involute, irregular margin. Capsule 4-seeded, 21 - 24 mm long, stipitate and with a short rostrum (i.e., sterile portion) to $2.5 \mathrm{~mm}$ long, glabrous; seeds only observed in immature state, face somewhat oblong, brown, surfaces appearing smooth but actually covered in dense short appressed hairs, seed base with a semicircular area of thickened pale bony tissue either side of the hilum. Fig. 2.

RECOGNITION. Ruellia domatiata is highly distinctive and unlikely to be confused with any other known species of Ruellia. It is allied to $R$. geayi but is very easily separated by, amongst other characters, having a short corolla tube up to $24 \mathrm{~mm}$ long with the basal cylindrical portion shorter than the abruptly expanded throat and with included stamens (vs tube longcylindrical and $45-62 \mathrm{~mm}$ long, with only a very short expanded throat, and stamens exserted); in the corolla being essentially glabrous (vs densely puberulous externally); in having much longer and wiry peduncles, the primary peduncle $30-110 \mathrm{~mm}$ long (vs 5 - $23 \mathrm{~mm}$ long and rigid, not wiry); in having longer calyx lobes, 7.5 - $12 \mathrm{~mm}$ long (vs 1.5 $6.8 \mathrm{~mm}$ long) and in the leaves having tuft-domatia in the axils of the primary veins beneath (absent in R. geayi).

In the key to the genus Ruellia in the Flore de Madagascar et des Comores (Benoist 1967), this new species would key out to $R$. cyanea (Nees) T. Anderson based on the presence of a clavate, stipitate capsule, calyx over $7 \mathrm{~mm}$ long and fused in the lower portion, corolla over $20 \mathrm{~mm}$ long with tube abruptly widened in the throat and a glabrous ovary. However, the two species are otherwise very different: $R$. cyanea has sessile or very shortly stalked axillary inflorescences, fruits with up to eight seeds, a more deeply divided calyx with acuminate lobes up to $20 \mathrm{~mm}$ long, persistent bracteoles and a pubescent corolla amongst other differences, and so is easily separated from R. domatiata.

DISTRIBUTION. North Madagascar, Antsiranana region (Map 1).

SPECIMENS EXAMINED. MADAGASCAR. Antsiranana: Diego-Suarez, $\mathrm{S}$ of Anivorano $\mathrm{N}$, environs of Ambalabao, c. $12^{\circ} 48^{\prime} \mathrm{S} 49^{\circ} 14^{\prime} \mathrm{E}$, fl. \& imm. fr. 10 March 1988, Cheek, Rakotozafy $\mathcal{E}^{\circ}$ Abdallah Salam B1409 (K! holotype; BR!, CAS!, COLO!, K!, MO!, P!, TAN isotypes); Fivondronana Antsiranana II, environ de Réserve Spéciale d'Ankarana, à $80 \mathrm{~km}$ au sud d'Antsiranana par route RN6, et l'est de l'ancien chantier Colas du Marotaolana, tout près du village d'Ambalabao, 1249'23"S 49¹6'26"E, fr. 3 April 1996, Andrianantoanina Eீ Bezara 957 (K!, MO, TAN).

HABITAT \& ECOLOGY. Ruellia domatiata is recorded from dry semi-deciduous forest and woodland of Garcinia, Pachypodium and Tisonia on limestone at 350-450 m alt. This dry forest habitat, which falls within the Western Dry Forest mapping unit of Moat \& Smith (2007), is widespread in the karst landscapes of the Ankarana plateau, where the woodland can become xerophytic with a significant succulent element including Aloe, Pachypodium, Euphorbia and Cyphostemma spp. CONSERVATION STATUS. Ruellia domatiata is currently known only from a single location just outside the northern boundary of the Ankarana Reserve. It has a known AOO of $8 \mathrm{~km}^{2}$. On Google Earth imagery (accessed $24^{\text {th }}$ February 2016), the forest in the vicinity of the collecting sites is fragmented, with significant amounts of clearance for settlement and agriculture evident. This is confirmed by field observations of extensive deforestation and development in the Ankarana region since the early 1990s (T. F. Daniel, pers. comm.). This area is also subject to mining for precious stones and building materials, and the forests are susceptible to increasingly frequent dry-season fires. All these factors are contributing to a decline in extent and quality of habitat for this species and so, based on our current knowledge, it is provisionally assessed as Critically Endangered - CR B2ab(iii). That said, there are large areas of intact and better protected dry forest on limestone within the Ankarana 


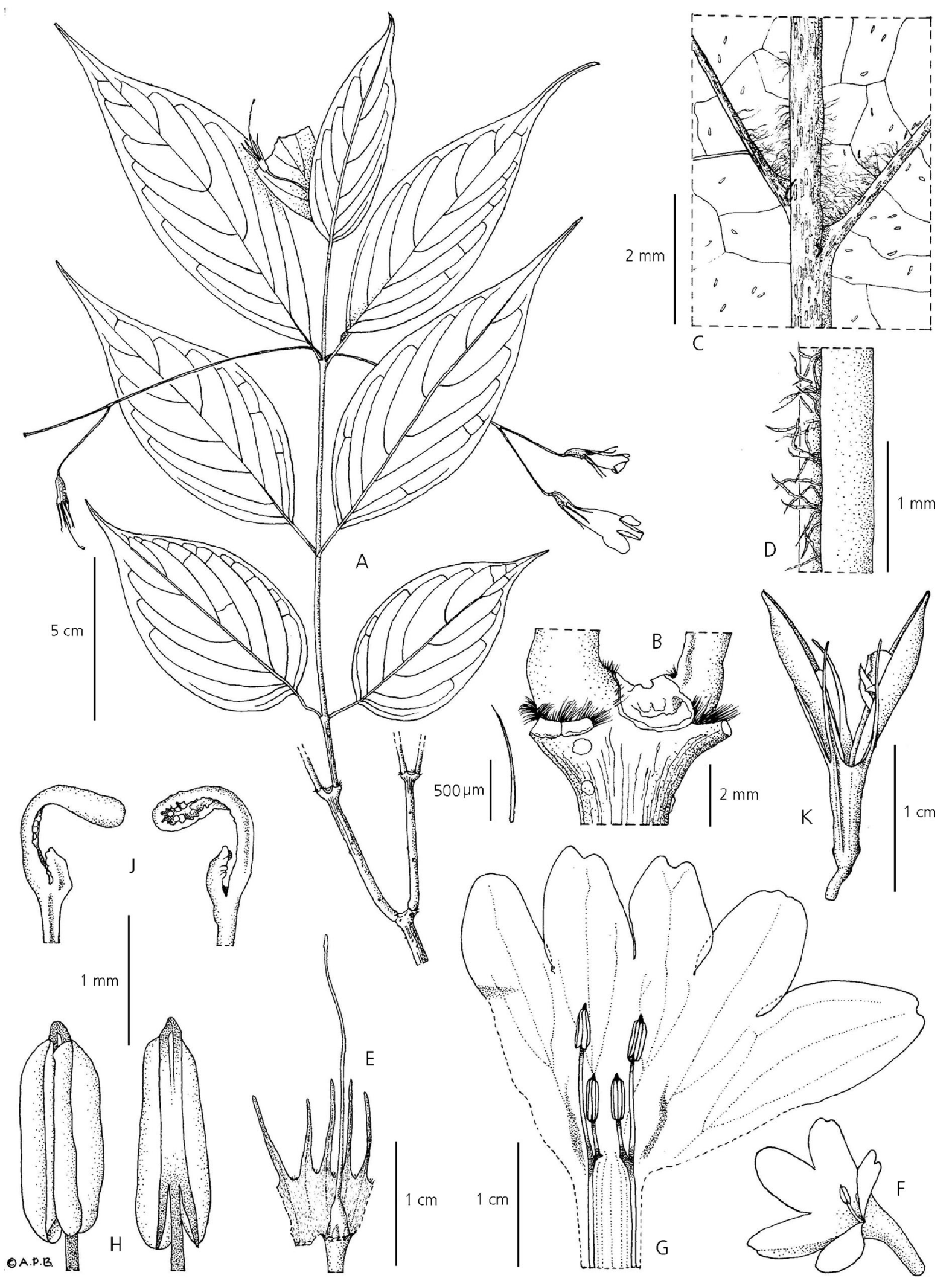

Fig. 2. Ruellia domatiata. A habit, flowering branch; B branch node with fallen leaves, showing tufts of stiff hairs; $C$ detail of abaxial leaf surface showing tuft-domatia; D detail of petiole, showing indumentum; E calyx, dissected and folded out, showing internal surface with pistil; F flower; $\mathrm{G}$ dissected corolla showing didynamous stamens, abaxial corolla lobe to the right, flattened; $\mathrm{H}$ detail of anther, ventral (L) and dorsal (R) views; J stigma in two views; K capsule within calyx. A - J from Cheek et al. B1409, K from Andrianantoanina \& Bezara 957. DRAWN BY ANDREW BROWN, 


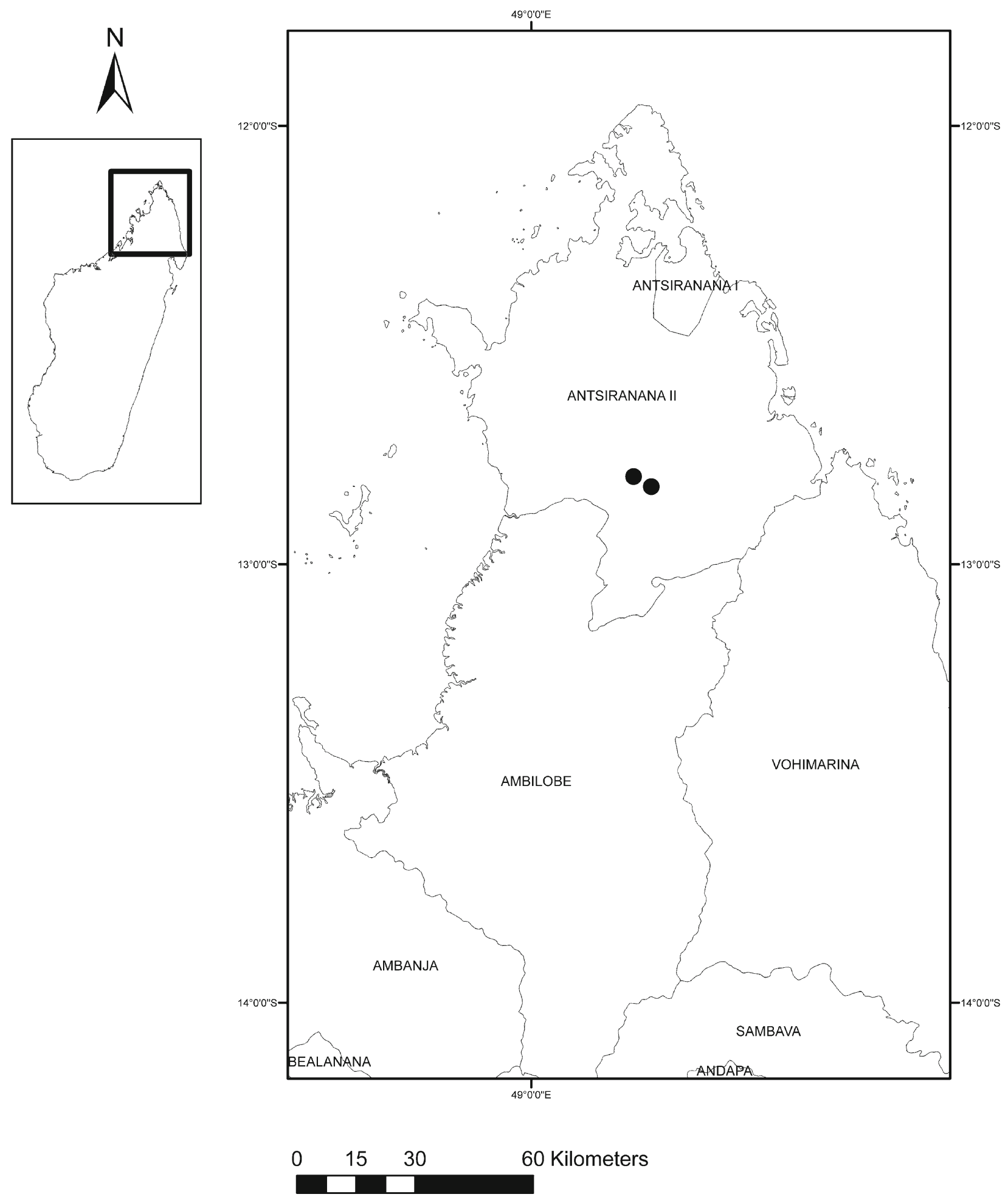

Map 1. The distribution of Ruellia domatiata in Madagascar. The place names on the map refer to the administrative districts of Antsiranana Province.

Reserve, including some extensive patches immediately to the south of the known sites for $R$. domatiata, and it is considered likely that this species will be found within the Reserve in the future. If this is the case, this provisional conservation assessment may be downgraded to Endangered or Vulnerable.

PHENOLOGY. From the two specimens seen, it appears that this species flowers at or towards the 
end of the main rainy season in March, the main rains falling in December - March in this region (Moat \& Smith 2007).

ETYMOLOGY. The species epithet "domatiata" denotes the fact that this species has conspicuous tuft-domatia on the leaves, an unusual character in the genus.

NOTES. The tufts of long, curled multicellular hairs in the axils of the principal veins and midrib on the underside of the leaf in this species are here interpreted as tuftdomatia, although there is no evidence of an associated depression or chamber for harbouring arthropods. Domatia have only rarely been recorded in the Acanthaceae: Watson \& Dallwitz (2015) noted that they have been reported in three (unspecified) genera in the family, manifested as hair tufts. Tufts of wooly hairs forming domatia in the axils of the major leaf veins have been recorded in the genus Mendoncia Vell. ex Vand. on Madagascar (Magnaghi \& Daniel 2014). There are also unpublished records of domatia within the large genus Justicia L. (T. F. Daniel, pers. comm.). Within Ruellieae, leaf domatia have been reported in some species of Mimulopsis Schweinf. and Epiclastopelma Lindau (Vollesen 2008), the latter genus now known to be nested within Mimulopsis (Tripp et al. 2013). To our knowledge, there have been no previous reports of tuft-domatia in Ruellia itself, but ant-occupied cavity domatia myrmecodomatia - occasionally occur in the stems of the South American R. inflata Rich. (E. A. T., pers. obs.).

\section{Acknowledgements}

We thank Stuart Cable (Conservation Department, Royal Botanic Gardens, Kew) and Hélène Ralimanana (Kew Madagascar Conservation Centre) for facilitating G.E.O.'s visit to Kew and Andrew Brown for the detailed illustration of the new species. Chrissie Prychid, (Lab Manager, Imaging and Electron Microscopy; Comparative Plant and Fungal Biology Department at Royal Botanic Gardens, Kew) is thanked for assistance with preparation of the SEM pollen images for the new species. Tom Daniel and an anonymous reviewer are thanked for their helpful review comments.

Open Access This article is distributed under the terms of the Creative Commons Attribution 4.0 International License (http://creativecommons.org/ licenses/by/4.0/), which permits unrestricted use, distribution, and reproduction in any medium, provided you give appropriate credit to the original author(s) and the source, provide a link to the Creative Commons license, and indicate if changes were made.

\section{References}

Benoist, R. (1967). Acanthacées. Tome I. In: H. Humbert (ed.), Flore de Madagascar et des Comores. Museum national d'Histoire naturelle, Laboratoire de Phanérogamie, Paris.

Darbyshire, I., Phillipson, P. B. \& Rakotonasolo, F. (2014). Additions to the genus Barleria in Madagascar. Kew Bull. 69: 9513. DOI 10.1007/s12225-0149513-1.

IUCN (2012). IUCNRed List Categories and Criteria. Version 3.1. Second Edition. IUCN Species Survival Commission, Gland \& Cambridge.

IUCN Standards and Petitions Subcommittee (2014). Guidelines for Using the IUCN Red List Categories and Criteria. Version 11. Prepared by the Standards and Petitions Subcommittee. [http://www.iucnredlist.org/documents/RedListGuidelines.pdf. Accessed: June 2015].

Madagascar Catalogue (2015). Catalogue of the Vascular Plants of Madagascar. Missouri Botanical Garden, St. Louis \& Antananarivo. [http:/ / www.efloras.org/madagascar. Accessed: January 2016].

Magnaghi, E. B. \& Daniel, T. F. (2014). Three new species of Mendoncia (Acanthaceae) from Madagascar. Novon 23: 187 - 196.

Moat, J. \& Smith, P. (eds). (2007). Atlas of the vegetation of Madagascar / Atlas de la vegetation de Madagascar. Royal Botanic Gardens, Kew.

Onjalalaina, G. E. \& Darbyshire, I. (2016). An endangered new species of Podorungia (Acanthaceae), with notes on the tribe Barlerieae in Madagascar. Kew. Bull. 71 (3) 44: 1 - 7. DOI 10.1007/S12225-016-9657-2.

Scotland, R. W. \& Vollesen, K. (2000). Classification of Acanthaceae. Kew Bull. 55: 513 - 589.

Tripp, E. A. (2007). Evolutionary relationships within the species-rich genus Ruellia (Acanthaceae). Syst. Bot. 32: 628 -649 .

\& Darbyshire, I. (2017). Phylogenetic relationships among Old World Ruellia L.: a new classification and reinstatement of the genus Dinteracanthus Schinz. Syst. Bot. In press

Daniel, T. F., Fatimah, S. \& McDade, L. A. (2013). Phylogenetic relationships within Ruellieae (Acanthaceae) and a revised classification. Int. J. Plant Sci. 174: 97 - 137.

Vollesen, K. (2008). Acanthaceae Part 1. In: H. J. Beentje \& S. A. Ghazanfar (eds), Flora of Tropical East Africa. Royal Botanic Gardens, Kew.

Watson, L. \& Dallwitz, M. J. (2015). The families of flowering plants: descriptions, illustrations, identification, and information retrieval. Version: 8th December 2015. delta-intkey.com 